Research Article

\title{
Coumarins and Polar Constituents from Eupatorium triplinerve and Evaluation of Their $\alpha$-Glucosidase Inhibitory Activity
}

\author{
Do Thi Viet Huong $\mathbb{D}^{1},{ }^{1}$ Phan Minh Giang ${ }^{\mathbb{D}},{ }^{1}$ and Vu Minh Trang $\mathbb{C}^{2}$ \\ ${ }^{1}$ Faculty of Chemistry, VNU University of Science, Vietnam National University, 19 Le Thanh Tong Street, Hanoi, Vietnam \\ ${ }^{2}$ VNU University of Education, Vietnam National University, 144 Xuan Thuy Street, Hanoi, Vietnam \\ Correspondence should be addressed to Phan Minh Giang; giangpm@vnu.edu.vn
}

Received 16 July 2020; Revised 25 October 2020; Accepted 26 October 2020; Published 2 December 2020

Academic Editor: Andrea Mastinu

Copyright (c) 2020 Do Thi Viet Huong et al. This is an open access article distributed under the Creative Commons Attribution License, which permits unrestricted use, distribution, and reproduction in any medium, provided the original work is properly cited.

In our study of antidiabetic compounds from the leaves of Eupatorium triplinerve Vahl. (Asteraceae), ten compounds were isolated from the methanol leaf extract. They were determined to be $\beta$-sitosterol (1), stigmasterol (2), $\beta$-sitosterol 3-O- $\beta$-Dglucopyranoside (3), ayapanin (4), ayapin (5), thymoquinol 5-O- $\beta$-D-glucopyranoside (6), thyrsifloside $(8)$, $(E)$-4-methoxymelilotoside (9), and kaempferol 3,7-di-O- $\beta$-D-glucopyranoside (10) by using ESI-MS, $1 \mathrm{D}\left({ }^{1} \mathrm{H}-,{ }^{13} \mathrm{C}-\right.$, DEPT) and $2 \mathrm{D}$ NMR (HSQC, HMBC, and NOESY) techniques. This is the first report of water-soluble compounds from E. triplinerve and compounds 6-10 were isolated for the first time from E. triplinerve. NMR profiling and HPLC analysis are fast and reliable methods to screen phytochemicals in plant samples. Due to their high concentrations in the leaf extracts of E. triplinerve, coumarins $\mathbf{4}$ and $\mathbf{5}$ could be fast screened by NMR profiling and RP-HPLC-PDA analysis. In the in vitro test for $\alpha$-glucosidase inhibition of compounds 4-9, compounds 4, 5, and 7 showed the enzymatic inhibition of $40 \%, 46 \%$, and $81 \%$, respectively, at $256 \mu \mathrm{g} / \mathrm{mL}$. An IC 50 value of $58.65 \pm 1.20 \mu \mathrm{g} / \mathrm{mL}(302 \mu \mathrm{M})$ was calculated for compound 7 which is lower than that of the positive control acarbose (IC 50 $197.33 \pm 2.51 \mu \mathrm{g} / \mathrm{mL} ; 306 \mu \mathrm{M})$.

\section{Introduction}

The genus Eupatorium (family Asteraceae) is a taxonomically complex group of species distributed mainly in Europe, eastern Asia, and North America. Studies on Eupatorium species have revealed diversity of secondary metabolites such as sesquiterpene lactones, flavonoids, diterpenes, benzofurans, pyrrolizidine alkaloids, chromenes, and thymol derivatives [1]. A number of Eupatorium species are employed in traditional medicine in the treatment of different pathologies and as a consequence bioactive natural compounds with cytotoxic, anti-inflammatory, antifungal, and antibacterial activities have been reported from the species. E. triplinerve Vahl. (syn. E. ayapana Vent., Ayapana triplinervis (Vahl.) R.M. King and H. Robinson) is a perennial and aromatic herb, $35-100 \mathrm{~cm}$ tall of the family Asteraceae. The plant was originated in the area from northern Brazil to Suriname and was introduced, cultivated, and naturalized long ago in some Caribbean islands, Africa, India, and South-East Asian countries. The leaves of $E$. triplinerve are used in folk medicine of India and South-East Asian countries as a heart stimulant, laxative, anticoagulant, stimulant, and tonic and for the treatment of yellow fever [2]. In Vietnam, the plant is popularly known as "Bả dột" and the leaves are used to heal wounds, snake bites, and stop bleeding. People also prepare tea from the twigs and leaves [3]. A number of studies investigated essential oils from different parts of $E$. triplinerve, showing variation of chemotypes such as 2,5-dimethoxy- $p$ cymene [4], $\beta$-caryophyllene [4], selina-4(15),7(11)-dien-8one [5], and 2-tert-butyl-1,4-methoxybenzene [6]. The leaves emit a distinct coumarin odour, and the isolation of ayapanin (or herniarin, 7-methoxycoumarin) and ayapin (or 6,7methylenedioxycoumarin) was reported. Ayapanin and ayapin showed toxicity to cancer cells including multidrug 
resistant cancer cells [6], haemostatic properties [7], blood coagulation, and phytoalexin activity to inhibit or destroy the invading bacteria, insects, and viruses $[8,9]$. Ayapanin reduced the number of abdominal constrictions in mice and decreased the time spent in paw licking and biting response in formalin assay [10]. Kumala and Sapitri reported toxicity test using brine shrimp lethality method that showed all of the fractions of methanol extract had toxicity $\left(\mathrm{LC}_{50}<1000 \mu \mathrm{g} /\right.$ $\mathrm{mL}$ ). The water extract had no toxicity. The highest $\mathrm{LC}_{50}$ was for the ethyl acetate $(24,42 \mu \mathrm{g} / \mathrm{mL})$ and the lowest $\mathrm{LC}_{50}$ was for the $n$-hexane $(238,66 \mu \mathrm{g} / \mathrm{mL})$ extracts [11]. Both ayapanin and ayapin are nontoxic and are effective when applied locally or when administered by subcutaneous injections or by mouth. They have no effect on respiration or on blood pressure [12]. In addition, ayapanin did not show antigenotoxic effects on human lymphocyte DNA damage using single-cell gel electrophoresis [13]. Therefore the reason for the toxicity of the $n$-hexane and ethyl acetate extracts is complex and may be related to minor nonpolar or volatile compounds which may be produced by plants either constitutively or in response to different biotic or abiotic stresses [14]. The high contents in E. triplinerve enable ayapanin and ayapin to be used as starting materials for pharmacological investigations involving coumarins such as antidiabetic activity [15], affinity to cannabinoid receptors (cannabimimetic ligands) [16] or cognitive enhancing activity through inhibiting oxidative stress and brain inflammation $[17,18]$. Till now, there has not been any report on the quantification of the two biologically active coumarins from the leaves of E. triplinerve. In this study, the principles $\mathbf{4}$ and $\mathbf{5}$ were analysed in the leaves of E. triplinerve by using proton NMR profiling and HPLC-PDA analysis.

Type II diabetes is a chronic metabolite disease caused mainly by excess levels of blood glucose and is a major cause of premature death, blindness, kidney failure, heart attack, stroke, and lower limb amputation [19]. Type II diabetes is characterized by hyperglycaemia as a consequence of insulin resistance and affects over $90 \%$ of patients diagnosed with this disease. Oral hypoglycemic medications currently used in the treatment of type II diabetes include sulfonylureas, meglitinides, biguanides, thiazolidinediones, $\alpha$-glucosidase inhibitors, and dipeptidyl peptidase-IV (DPP-IV) inhibitors. The antidiabetic drugs such as metformin, pioglitazone, thiazolidinedione, and acarbose decrease hepatic glucose output and reduce starch digestibility. Due to the side effects of these agents such as severe hypoglycemia, weight gain, and gastrointestinal disturbances medicinal plants with antidiabetic properties have been investigated for finding safer and cost-effective antidiabetic drugs [20]. Coumarins and cinnamic acid derivatives have been reported as antidiabetic agents $[15,21]$. Currently, the inhibition of starchhydrolysing enzymes such as $\alpha$-amylase and $\alpha$-glucosidase are one of the approaches to reduce hyperglycemia by retarding glucose uptake. In the present study, coumarins 4 and 5, thymoquinol glucoside 6, and o-hydroxycinnamic acid derivatives 7-9 were isolated from the leaves of E. triplinerve collected in Vietnam and evaluated for the enzymatic inhibitory activity against $\alpha$-glucosidase.

\section{Materials and Methods}

2.1. General Procedures. Electron-spray ionization-mass spectrometry (ESI-MS) spectra were measured on an Agilent 1100 LC-MSD-Trap-SL system (Agilent Technologies, USA). ${ }^{1} \mathrm{H}-\mathrm{NMR},{ }^{13} \mathrm{C}-\mathrm{NMR}$, and DEPT spectra were recorded in $\mathrm{CDCl}_{3}$ using a Bruker Avance $500 \mathrm{NMR}$ spectrometer. The chemical shifts are expressed in ppm relative to tetramethylsilane (TMS) as an internal standard. The ${ }^{1} \mathrm{H}-\mathrm{NMR}$ spectrum was recorded with spectrometer frequency (SF) 500.20 MHz. The ${ }^{13} \mathrm{C}-\mathrm{NMR}$ spectrum was recorded with SF 125.13 MHz. High-performance liquid chromatography (HPLC) analysis was carried out with a Shimadzu 20A HPLC system (Shimadzu corporation, Japan) equipped with a LC-20AD pump, SIL-20AC auto-sampler, DGU-20A5R degassing unit, SPD-M20A photodiode array (PDA) detector, and CBM-20A controller system. Silica gel 40-63 $\mu \mathrm{m}$ (Merck, Germany), reversed-phase C-18 silica gel 40-63 $\mu \mathrm{m}$ (Merck, Germany), and highly porous Diaion HP-20 (Mitsubishi, Japan) were used for column chromatography (CC). Precoated silica gel Merck $60 \mathrm{~F}_{254}$ aluminum plates were used for thin-layer chromatography (TLC).

2.2. Plant Material. The leaves of E. triplinerve Vahl. were collected in Nghe An province, Vietnam, in July 2016. The plant material was taxonomically identified by Dr. Nguyen Thi Kim Thanh, Faculty of Biology, VNU University of Science, Vietnam National University, Hanoi. A voucher sample (ET-616) was deposited at the same institution.

2.3. Extraction and Isolation of Compounds 1-10. The fresh leaves $(7.5 \mathrm{~kg})$ were air-dried in the shade, then oven-dried at $45^{\circ} \mathrm{C}$, and ground into powder. The dry powder $(2 \mathrm{~kg})$ was extracted with $\mathrm{MeOH}$ at room temperature for 3 days, and the extraction was repeated for three times. The extracts obtained after filtration were concentrated under reduced pressure to yield a methanol extract. The methanol extract was suspended in water and extracted successively with $n$ hexane and dichloromethane to give the corresponding $n$ hexane- $(86 \mathrm{~g})$ and dichloromethane-soluble $(50 \mathrm{~g})$ fractions after in vacuo evaporation. Separation of a part of the $n$ hexane-soluble fraction $(17.2 \mathrm{~g})$ by CC over silica gel with gradient elution of $n$-hexane-acetone $90: 1,49: 1,19: 1,9: 1$, $3: 1,1: 1,1: 2$ gave 9 fractions. Fractions $4(0.62 \mathrm{~g})$ and 5 $(0.91 \mathrm{~g})$ were purified by CC over silica gel, eluting with $n$ hexane-EtOAc $12: 1,9: 1,7: 1,5: 1,3: 1,2: 1,1: 1$ to give a mixture of 1 and 2 (110 $\mathrm{mg}$ and $38.9 \mathrm{mg}$, respectively). Fraction $6(6.1 \mathrm{~g})$ was separated by CC over silica gel, eluting with $\mathrm{CH}_{2} \mathrm{Cl}_{2}-\mathrm{MeOH} 15: 1$ to give $3(7 \mathrm{mg})$ and $\mathbf{4}(109 \mathrm{mg})$. Fraction 9 ( $1 \mathrm{~g}$ ) was separated by CC over silica gel, eluting with $n$-hexane-EtOAc $7: 1,5: 1,3: 1,2: 1,1: 1,1: 2$ to give 5 $(5.3 \mathrm{mg})$. A part of the dichloromethane-soluble fraction $(1.1 \mathrm{~g})$ was washed with $n$-hexane and then acetone to give 5 (45 mg). The residue was separated by CC over RP-18, eluting with $70 \% \mathrm{MeOH}-\mathrm{H}_{2} \mathrm{O}$. The fraction eluting with $70 \%$ $\mathrm{MeOH}-\mathrm{H}_{2} \mathrm{O}(882.5 \mathrm{mg})$ was separated by CC over silica gel, eluting with $\mathrm{CH}_{2} \mathrm{Cl}_{2}$-acetone $90: 1,49: 1,25: 1,15: 1$ to give $4(13.5 \mathrm{mg})$. The water phase was concentrated and passed 
through a Diaion HP-20 column eluting with $\mathrm{MeOH}-\mathrm{H}_{2} \mathrm{O}$ $2: 3,3: 2$ and $\mathrm{MeOH}$ to give three corresponding fractions 1-3. Fr. 1 (6.6 g) was separated by silica gel CC, eluting with EtOAc-MeOH $30: 1,25: 1,15: 1,12: 1,9: 1,6: 1,3: 1$ to give four subfractions $1-4$. Subfr. 1 was separated by silica gel CC, eluting with $\mathrm{CH}_{2} \mathrm{Cl}_{2}-\mathrm{MeOH} 20: 1,15: 1,10: 1,7: 1,5,3: 1,3$ : 1 and purified by Sephadex LH-20, eluting with $\mathrm{MeOH}$ to give $6(5 \mathrm{mg})$. Fr. $2(17.2 \mathrm{~g})$ was separated by silica gel CC, eluting with $\mathrm{CH}_{2} \mathrm{Cl}_{2}-\mathrm{MeOH} 60: 1,50: 1,40: 1,30: 1$ to give 2 subfractions 1 and 2 . Subfr. 1 was purified by silica gel CC, eluting with $\mathrm{CH}_{2} \mathrm{Cl}_{2}$-EtOAc $45: 1,40: 1,30: 1,25: 1,20: 1$ to give $7(5 \mathrm{mg})$. Subfr. $2(3 \mathrm{~g})$ was separated by CC over Sephadex LH-20, eluting with $\mathrm{MeOH}$ to give $8(5 \mathrm{mg})$, a mixture of $\mathbf{8} / \mathbf{9}(20 \mathrm{mg})$, and $\mathbf{1 0}(5 \mathrm{mg})$.

\subsection{NMR Profiling of the Methanol or Boiling Water Leaf} Extracts. The dried leaf powder $(240 \mathrm{~g})$ was extracted with methanol at room temperature for three days or with boiling water for $24 \mathrm{~h}$. The extracts were separately filtered and evaporated to dryness under reduced pressure to give the corresponding methanol or water extract. A small part of the methanol or water extract $(30 \mathrm{mg})$ was dissolved in pure methanol and extracted using a Lichrolut $^{\circledR}$ RP-18 SPE cartridge (Merck, $40-60 \mu \mathrm{m}$ ) with a solvent gradient of $70 \%$, $80 \%$, and $100 \% \mathrm{MeOH}-\mathrm{H}_{2} \mathrm{O}$. The fractions eluting with $70 \%$ $\mathrm{MeOH}-\mathrm{H}_{2} \mathrm{O}$ were concentrated under reduced pressure to afford two NMR samples. $5 \mathrm{mg}$ of each sample was dissolved in $\mathrm{CD}_{3} \mathrm{OD}$ and directly analysed by ${ }^{1} \mathrm{H}$-NMR spectroscopy at $500 \mathrm{MHz}$ frequency.

2.5. HPLC Analysis of the Methanol Leaf Extract. The dried leaf powder $(80 \mathrm{~g})$ was extracted with $\mathrm{MeOH}$ at room temperature for 1 day. The solution was filtered and then evaporated to dryness under reduced pressure. The methanol leaf extract $(220 \mathrm{mg})$ was dissolved with $2 \mathrm{~mL}$ acetonitrile of HPLC grade (Merck, Germany). The reversedphase solid-phase extraction (RP-SPE) of the solution eluting with $\mathrm{MeOH}$ of HPLC grade (Merck, Germany) was performed to remove impurities. The sample was filtered through a Millipore $0.45 \mu \mathrm{m}$ membrane filter. Two standard solutions $(100 \mu \mathrm{g} / \mathrm{mL})$ were prepared by dissolving compounds $\mathbf{4}$ and $\mathbf{5}$ in MeOH of HPLC grade (Merck, Germany). The calibration curves were constructed by plotting the peak areas versus the corresponding concentrations (expressed as $\mu \mathrm{g} / \mathrm{mL}$ ) of each standard. A Shimadzu 20A HPLC system equipped with a photodiode array detector (PDA) was used for the qualitative and quantitative analysis of samples. An analytical column C-18 $(4.6 \mathrm{~mm} \times 250 \mathrm{~mm}, 5 \mu \mathrm{m})$, a gradient mobile phase of $44 \%$ acetonitrile- $\mathrm{H}_{2} \mathrm{O}(15 \mathrm{~min}$.), a flow rate of $1 \mathrm{~mL} / \mathrm{min}$., an injection volume of $10 \mu \mathrm{L}$, and column temperature $25^{\circ} \mathrm{C}$ were used for the HPLC analysis. The UV detection wavelength was set at $306 \mathrm{~nm}$. All the measurements were performed in triplicate.

2.6. $\alpha$-Glucosidase Inhibitory Activity of Compounds 4-9 and 11. The inhibition of $\alpha$-glucosidase activity was carried out following the method described by Li et al. [22]. A $2.5 \mathrm{mM}$ solution of $p$-NPG ( $p$-nitrophenyl $\alpha$-D-glucopyranoside) (Sigma-Aldrich) and $0.2 \mathrm{U} / \mathrm{mL} \alpha$-glucosidase from Saccharomyces cerevisiae (Sigma-Aldrich) were prepared in $100 \mathrm{mM}$ potassium phosphate buffer $\mathrm{pH}$ 6.8. Compounds 4-9 and compound 10 previously isolated from the leaves of E. japonicum [23] were prepared in dimethylsulfoxide (DMSO) (Sigma-Aldrich) and serially diluted in the concentrations of $1,4,16,64$, and $256 \mu \mathrm{g} / \mathrm{mL} .10 \mu \mathrm{L}$ of sample was added to a reaction mixture consisting of $40 \mu \mathrm{L}$ of $100 \mathrm{mM}$ phosphate buffer $\mathrm{pH} 6.8$ and $25 \mu \mathrm{L}$ of $0.2 \mathrm{U} / \mathrm{mL}$ $\alpha$-glucosidase in a 96-well microplate and the reaction mixture was incubated for $10 \mathrm{~min}$ at $37^{\circ} \mathrm{C}$. Then $25 \mu \mathrm{L}$ of $2.5 \mathrm{mM} p$-NPG was added and the reaction mixture was further incubated for $20 \mathrm{~min}$ at $37^{\circ} \mathrm{C}$. After $30 \mathrm{~min}, 100 \mathrm{mM}$ sodium carbonate solution $(100 \mu \mathrm{L})$ was added to stop reaction. The absorbance of the mixture was measured at $\lambda$ $410 \mathrm{~nm}$ on an UV-VIS spectrophotometer (Biotek Instruments, USA). To make a control reaction, the tested sample was replaced by $10 \mu \mathrm{L}$ of $100 \mathrm{mM}$ phosphate buffer (pH 6.8). Acarbose was used as the reference standard. The experiments were repeated three times. The $\alpha$-glucosidase inhibitory activity was calculated using the following equation, where $\mathrm{A}_{\text {control }}$ is the absorbance of the control, $\mathrm{A}_{\text {sample }}$ is the absorbance of the sample: $\alpha$-glucosidase inhibitory activity $(\%)=\left(\mathrm{A}_{\text {control }}-\mathrm{A}_{\text {sample }}\right) / \mathrm{A}_{\text {control }} \times 100 . \mathrm{IC}_{50}$ (half maximal inhibitory concentration) was calculated using Tablecurve software. All analyses were performed in triplicate and data were reported as mean \pm SEM.

\section{Results and Discussion}

3.1. Isolation and MS/NMR Elucidation of Compounds. The dried powdered leaves of E. triplinerve were extracted with $\mathrm{MeOH}$ at room temperature to yield a methanol extract. The methanol extract was fractionated into $n$-hexane-, dichloromethane-, and water-soluble fractions. Separation of the $n$-hexane-, dichloromethane-, and water-soluble fractions by repeated CC over different adsorbents such as silica gel, Diaion HP-20, Sephadex LH-20, and RP-18 using stepwise gradient elution gave phytosterols 1-3, coumarins 4 and 5, thymoquinol glucoside 6, $o$-hydroxycinnamic acid derivatives 7-9, and kaempferol diglucoside 10. Structures of the isolated compounds were determined as $\beta$-sitosterol (1) [24], stigmasterol (2) [24], $\beta$-sitosterol 3-O- $\beta$-D-glucopyranoside (3) [25], ayapanin (4) [26, 27], ayapin (5) [28], thymoquinol 5-O- $\beta$-D-glucopyranoside (6) [29], (E)-4-hydroxy-2-methoxycinnamic acid (7) [30,31], thyrsifloside (8) [32], (E)-4-methoxymelilotoside (9) [33], and kaempferol 3,7-di-O- $\beta$-D-glucopyranoside (10) [34] (Figure 1) by comparing their spectroscopic data $\left(\mathrm{MS},{ }^{1} \mathrm{H}-\right.$, and ${ }^{13} \mathrm{C}-$ NMR) (Figures S1-S30) with the reported literature values. Compound 8 was isolated in its pure form and compound 9 was isolated in a nonseparable mixture of $\mathbf{8}$ and $\mathbf{9}$ (molar ratio $1: 1$ as determined by ${ }^{1} \mathrm{H}-\mathrm{NMR}$ intensity). The locations of the substituents of compounds $\mathbf{6 , 8}, \mathbf{8}$, and $\mathbf{9}$ were assigned by using heteronuclear single-quantum correlation (HSQC), heteronuclear multibond correlation (HMBC), and nuclear Overhauser effect spectroscopy (NOESY) spectra (Figure 2). In compound 6, key HMBC correlations were 

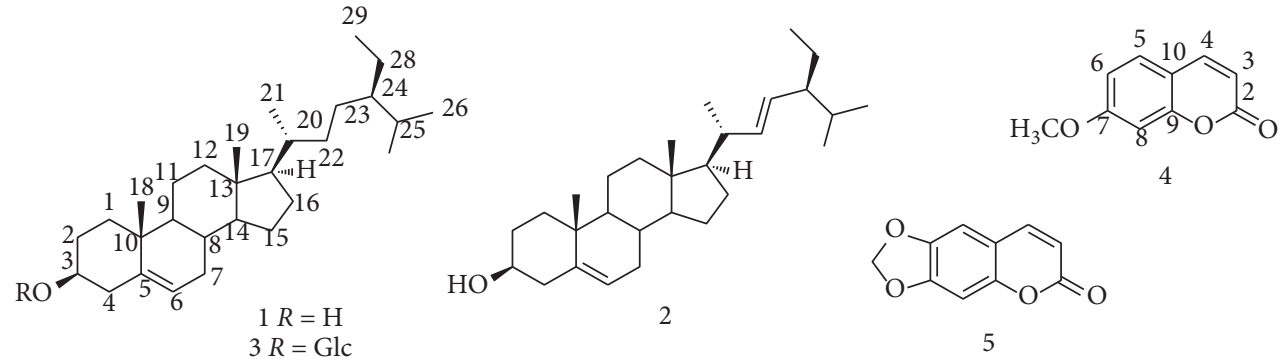<smiles>CC(C)c1cc(O)c(I)cc1Cl</smiles><smiles>[R]c1ccc(C=CC(=O)O)c([R2])c1</smiles>

$7 R_{1}=\mathrm{OH}, R_{2}=\mathrm{OCH}_{3}$

$9 R_{1}=\mathrm{OCH}_{3}, R_{2}=$ OGlc

$11 R_{1}=\mathrm{H}, R_{2}=$ OGlc

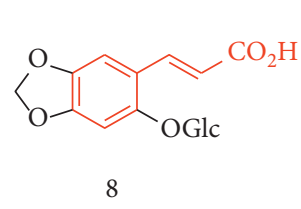

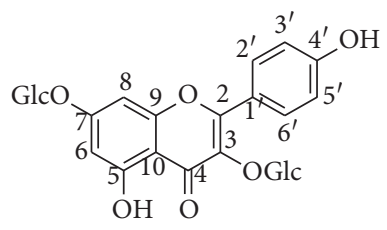

10

Figure 1: Structures of compounds 1-10 from E. triplinerve and $\mathbf{1 1}$ from E. japonicum.
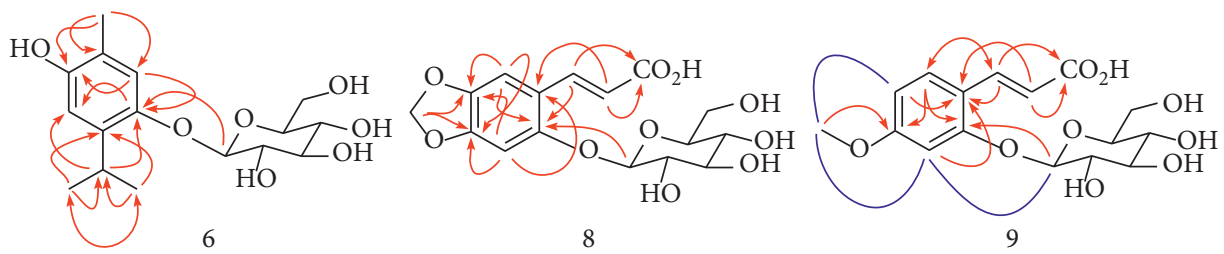

Figure 2: HMBC $(\longrightarrow)$ and NOESY $(-)$ correlations of compounds $\mathbf{6 , 8}$, and 9.

observed between $\mathrm{CH}_{3}-7\left(\delta_{\mathrm{H}} 2.15\right)$ and $\mathrm{C}-1\left(\delta_{\mathrm{C}} 123.3\right), \mathrm{C}-2$ $\left(\delta_{\mathrm{C}} 151.8\right)$, between $\mathrm{H}-8\left(\delta_{\mathrm{H}} 3.5\right)$ and $\mathrm{C}-3\left(\delta_{\mathrm{C}} 113.1\right), \mathrm{C}-5\left(\delta_{\mathrm{H}}\right.$ $149.2)$, and between Glc-1 $\left(\delta_{\mathrm{H}} 4.72\right)$ and $\mathrm{C}-5\left(\delta_{\mathrm{C}} 149.2\right)$. In compound 8, key HMBC correlations for the assignment of the glucopyranosyl moiety were observed between H-7 $\left(\delta_{\mathrm{H}}\right.$ 8.13) and $\mathrm{C}-2\left(\delta_{\mathrm{C}} 154.0\right)$, between $\mathrm{H}-6\left(\delta_{\mathrm{H}} 7.13\right)$ and $\mathrm{C}-2$, and between Glc-1 $\left(\delta_{\mathrm{H}} 4.85\right)$ and C-2. In compound 9, key $\mathrm{HMBC}$ correlations for the assignment of the glucopyranosyl moiety and the methoxy group were observed between H-6 $\left(\delta_{\mathrm{H}} 7.57\right)$ and C-2 $\left(\delta_{\mathrm{C}} 159.0\right)$, between $4-\mathrm{OCH}_{3}$ $\left(\delta_{\mathrm{H}} 3.87\right)$ and C-4 $\left(\delta_{\mathrm{C}} 164.4\right)$, and between Glc-1 $\left(\delta_{\mathrm{H}} 4.98\right)$ and C-2. Further confirmation was obtained from the NOESY spatial interactions between $\mathrm{H}-5\left(\delta_{\mathrm{H}} 6.67\right)$ and 4$\mathrm{OCH}_{3}$, between $4-\mathrm{OCH}_{3}$ and $\mathrm{H}-3\left(\delta_{\mathrm{H}} 6.87\right)$, and between $\mathrm{H}-3$ and Glc- 1 . The ${ }^{1} \mathrm{H}-\mathrm{NMR}$ spectra of $\mathbf{4}$ and $\mathbf{5}$ were also recorded in different NMR solvents $\left(\mathrm{CDCl}_{3}, \mathrm{CD}_{3} \mathrm{OD}\right.$, and DMSO- $d_{6}$ ) and the signals were assigned to ease NMR identification of the compounds in different NMR solvents. Compounds 6-10 were isolated for the first time from E. triplinerve. The isolation of compounds has not showed the presence of alkaloids, saponins, triterpenoids, depsides, and depsidones which were detected in the previous phytochemical screening by using color reactions [35]. However, high concentration of coumarins and the presence of sterols in the leaves are in line with most of the phytochemical screenings [35]. In the genus Eupatorium, derivatives of 2-O-hydroxycinnamic acid and 2-Oglucopyranosylcinnamic acid were isolated from E. micranthum, while thymols were reported in E. fortunei [1]. Compounds 8 and 9 are glycosidic precursors of compounds 5 and 4, respectively. Under enzymatic conditions, they can be converted into nonglycosidic derivatives 2-hydroxy-6,7-methylenedioxy-trans-cinnamic acid (8a) and 2-hydroxy-4-methoxy-trans-cinnamic acid (9a), respectively. Compound 4 would be formed from $9 a$ and compound 5 from 8a via photoisomerization of the trans double bond to cis and subsequent ring closure to the lactones (Figure 3) [30].

3.2. $\alpha$-Glucosidase Inhibitory Activity. Type II diabetes mellitus is as metabolic disease mainly caused by the accumulation of excess sugar in the body. The enzyme $\alpha$-glucosidase breaks down large starch polysaccharides into monosaccharides or disaccharides. Thus, inhibiting the enzymatic activity of $\alpha$-glucosidase may reduce absorption of glucose in the body. In the in vitro $\alpha$-glucosidase inhibitory activity test, the substrate $p$-nitrophenyl $\alpha$-D-glucopyranoside (pNPG) is hydrolyzed by $\alpha$-glucosidase to release $p$-nitrophenyl which can be monitored at $405 \mathrm{~nm}$. The results are expressed as percentage inhibition (\%) and the concentration of an inhibitor required to inhibit $50 \%$ of enzyme activity $\left(\mathrm{IC}_{50}\right)$ is determined [36]. The inhibitory activity of compounds isolated from E. triplinerve against $\alpha$-glucosidase is reported in Table 1 . Compounds $\mathbf{4}, \mathbf{5}$, and 7 showed the highest enzyme inhibitory activity at $256 \mu \mathrm{g} / \mathrm{mL}$ $\left(40 \%, 46 \%\right.$, and $81 \%$, respectively). An $\mathrm{IC}_{50}$ of $58.65 \pm 1.20 \mu \mathrm{g} / \mathrm{mL}(302 \mu \mathrm{M})$ was calculated for compound 7 , while the positive control acarbose showed a higher $\mathrm{IC}_{50}$ value of $197.33 \pm 2.51 \mu \mathrm{g} / \mathrm{mL}(306 \mu \mathrm{M})$. The other related $o$ - 


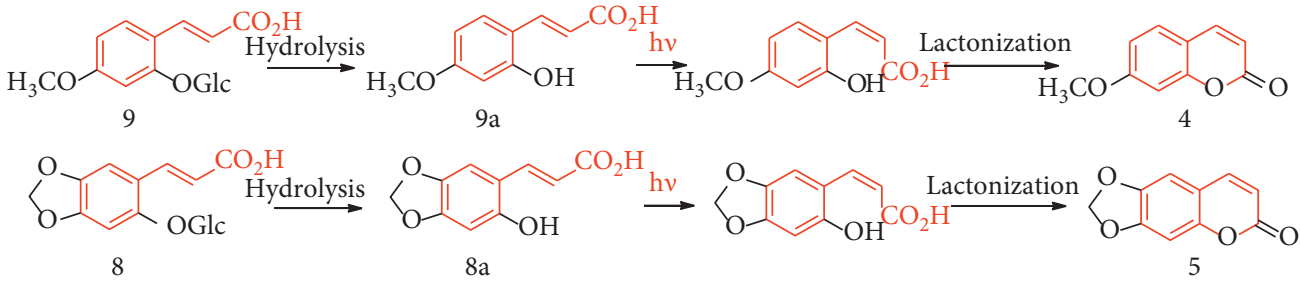

Figure 3: Plausible biosynthesis of $\mathbf{4}$ from $\mathbf{9}$ and $\mathbf{5}$ from $\mathbf{8}$ in E. triplinerve.

TABLe 1: $\alpha$-glucosidase inhibitory activity of compounds 4-9 and 11.

\begin{tabular}{|c|c|c|c|c|c|c|}
\hline \multirow{2}{*}{ Compound } & \multicolumn{5}{|c|}{$\alpha$-glucosidase inhibitory activity (\%) } & \multirow{2}{*}{$\mathrm{IC}_{50}(\mu \mathrm{g} / \mathrm{mL})(\mu \mathrm{M})$} \\
\hline & $256 \mu \mathrm{g} / \mathrm{mL}$ & $64 \mu \mathrm{g} / \mathrm{mL}$ & $16 \mu \mathrm{g} / \mathrm{mL}$ & $4 \mu \mathrm{g} / \mathrm{mL}$ & $1 \mu \mathrm{g} / \mathrm{mL}$ & \\
\hline 4 & 40 & 38 & 35 & 30 & 25 & $>256$ \\
\hline 5 & 46 & 41 & 38 & 30 & 19 & $>256$ \\
\hline 6 & 2 & 0 & 0 & 0 & 0 & $>256$ \\
\hline 7 & 81 & 53.5 & 22 & 16 & 0 & $58.65 \pm 1.20(302)$ \\
\hline 8 & 2 & 0 & 0 & 0 & 0 & $>256$ \\
\hline $8 / 9^{*}$ & 2 & 0 & 0 & 0 & 0 & $>256$ \\
\hline 11 & 2 & 0 & 0 & 0 & 0 & $>256$ \\
\hline
\end{tabular}

${ }^{* 1}$ H-NMR: molar ratio $1: 1$.

hydroxycinnamic acids including 8, a mixture of 8/9 (molar ratio 1:1), and $\mathbf{1 1}$ (compound $\mathbf{1 1}$ was isolated from E. japonicum [23]) and thymoquinol glucoside 6 did not show any $\alpha$-glucosidase inhibitory activity (2\% inhibitory activity at $256 \mu \mathrm{g} / \mathrm{mL}$ for all compounds investigated). (E)cinnamic acid does not inhibit $\alpha$-glucosidase from yeasts, but $o$-hydroxy or $o$-methoxy substituents increase the activity of the derivatives and the potency is higher for the methoxy group $[15,35,36]$. The structure of compound 7 possessing a methoxy group at C-2 and a hydroxy group at C-4 matched well the above-mentioned structural requisite. However, the activity was lost in compounds $\mathbf{8}, \mathbf{1 0}$, and a mixture of compounds $\mathbf{8 / 9}$ (molar ratio $1: 1$ ) when the 2hydroxy group was blocked by a glucopyranosyl group in spite of the presence of 4-methoxy group in 9. Thus, the importance of 2-hydroxy or 2-methoxy group in modulating $\alpha$-glucosidase inhibitory activity of $(E)$-cinnamic acids was confirmed which is in line with the previously published results $[21,36,37]$. The results of the present investigation are an additional contribution to the development of novel antidiabetic agents derived from $(E)$-cinnamic acid.

3.3. HPLC Analysis of Coumarins 4 and 5. HPLC analysis of the leaf methanol extract revealed coumarins $\mathbf{4}$ and $\mathbf{5}$ as the major compounds in the extract. An optimized HPLC condition using a mobile phase of $44 \%$ acetonitrile in deionized $\mathrm{H}_{2} \mathrm{O}$ in 15 min was used to effectively separate compounds 4 and 5 . With the wavelength of a PDA (photodiode array), detector set at $306 \mathrm{~nm}$ the HPLC chromatogram (Figures 4 and S33) showed two main resolved peaks of compound 4 at $\mathrm{R}_{t} 5.304 \mathrm{~min}$ and compound 5 at $\mathrm{R}_{t} 4.628 \mathrm{~min}$. Compounds were identified on the basis of $\mathrm{R}_{t}$ comparison with those of the standard compounds 4 and 5. Polar compounds including 6-10 were not well separated and they appeared as a broad band at $\mathrm{R}_{t}$ about $2.5 \mathrm{~min}$ in the

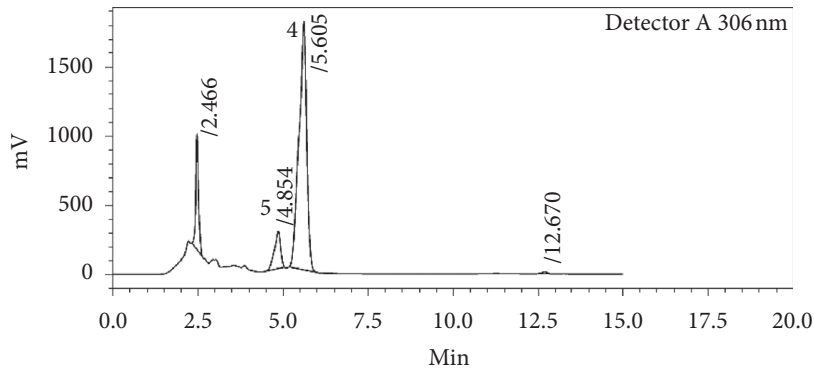

Figure 4: HPLC analysis of compounds $\mathbf{4}$ and $\mathbf{5}$ in the methanol leaf extract.

HPLC chromatogram. Thus, the HPLC method was suitable for analysing the contents of compounds 4 and 5 . The calibration curves of compounds $\mathbf{4}$ and $\mathbf{5}$ were constructed, injecting $20 \mu \mathrm{L}$ of each standard compound (5-100 ppm) (Figure S34). Using the Shimadzu LabSolutions HPLC software, each of the peaks was integrated to get the area values. The calibration curves were constructed by plotting area versus concentration with a correlation coefficient $R^{2}>0.990$. Based on the calibration curve, the methanol leaf extract was determined to contain $16.69 \%$ of compound 4 and $2.02 \%$ of compound 5 . Thus, the amounts of compounds $\mathbf{4}$ and $\mathbf{5}$ in the dry leaves of E. triplinerve collected in July in Vietnam were calculated as $2.63 \%$ and $0.32 \%$, respectively.

3.4. NMR Profiling of Coumarins 4 and 5. At present, ${ }^{1} \mathrm{H}-$ NMR spectroscopy has become a frequently used technique for metabolic fingerprinting. In addition, ${ }^{1} \mathrm{H}-\mathrm{NMR}$ spectroscopy has been used in the qualitative and quantitative assessment of secondary plant metabolites as well as quality 
control in food science and technology. One of the major advantages of NMR techniques is their reproducibility with rich structure information and applicability to a wide range of plant metabolites [38-40]. Coumarins have been successfully analysed in a few studies by ${ }^{1} \mathrm{H}-\mathrm{NMR}$ profiling [41, 42]. Compounds 4 and 5 could be extracted from the leaves of E. triplinerve by extraction with an alcohol such as methanol and boiling water. The methanol and boiling water extracts from the dry leaves of E. triplinerve were analysed by ${ }^{1} \mathrm{H}-\mathrm{NMR}$ spectra in this study. Solid-phase extraction (SPE) of the extracts eluting with $70 \% \mathrm{MeOH}-\mathrm{H}_{2} \mathrm{O}$ afforded the analytical samples. The following NMR parameters were used for the analysis: solvent $0.5 \mathrm{~mL} \mathrm{CD}_{3} \mathrm{OD}$ in $5-\mathrm{mm} \mathrm{NMR}$ tubes, 16 scans, acquisition time $3.2767999 \mathrm{sec}$, temperature $299.0 \mathrm{~K}$, spectral width $10000 \mathrm{~Hz}$, and line broadening $0.3 \mathrm{~Hz}$. FIDs were Fourier transformed with FIDRES 0.152588 , GB 0, and PC 1.0. Figures S31 and S32 showed the representative ${ }^{1} \mathrm{H}-\mathrm{NMR}$ spectra of the methanol or water extracts, respectively. Referencing was to the lock solvent. The ${ }^{1} \mathrm{H}$-NMR spectra of the standards $\mathbf{4}$ and $\mathbf{5}$ were prepared in $0.5 \mathrm{~mL}$ of $\mathrm{CD}_{3} \mathrm{OD}$ in $5 \mathrm{~mm}$ NMR tubes. By using highfield $500 \mathrm{MHz}$ NMR spectrometer, the signals of compounds 4 and 5 were resolved in both extracts. The identification match was based on chemical shifts, coupling, peak shape, and peak intensity data for individual compounds. Coumarins 4 and 5 were confirmed to be the abundant compounds in the extracts; their signal intensity ratio was about $15: 1$ in the methanol extract and about $10: 1$ in the water extract. These findings well supported the results obtained via the quantitative HPLC analysis. The concentrations of polar compounds 6-10 may be too low for the reliable detection by NMR techniques. Proton chemical shifts of compounds 4 and 5 in the extracts are summarized in Table S1. The ${ }^{1} \mathrm{H}-\mathrm{NMR}$ spectrum of compound $\mathbf{4}$ in the extracts was in accordance with that of the standard 4 in $\mathrm{CD}_{3} \mathrm{OD}$, showing the signals of a lactone ring of the coumarin structure at $\delta_{\mathrm{H}} 6.27(1 \mathrm{H}, d, J=9.5 \mathrm{~Hz}, \mathrm{H}-3)$ and 7.93 $(1 \mathrm{H}, d, J=9.5 \mathrm{~Hz}, \mathrm{H}-4)$, three aromatic protons with characteristic splitting of a 1,3,4-trisubstituted benzene ring at $\delta_{\mathrm{H}}$ $6.93(1 \mathrm{H}, \mathrm{br} s, \mathrm{H}-8), 6.96(1 \mathrm{H}, \mathrm{dd}, J=8.5 \mathrm{~Hz}, 2.5 \mathrm{~Hz}, \mathrm{H}-6)$, and $7.57(1 \mathrm{H}, d, J=8.5 \mathrm{~Hz}, \mathrm{H}-5)$, and an aromatic methoxy group at $\delta_{\mathrm{H}} 3.90\left(3 \mathrm{H}, s, 7-\mathrm{OCH}_{3}\right)$. The characteristic proton signals of compound 5 in the extracts matched the signals of the standard 5 in $\mathrm{CD}_{3} \mathrm{OD}$. The signals of a lactone ring of the coumarin structure at $\delta_{\mathrm{H}} 6.29(1 \mathrm{H}, d, J=9.5 \mathrm{~Hz}, \mathrm{H}-3)$ and $7.90(1 \mathrm{H}, d, J=9.5 \mathrm{~Hz}, \mathrm{H}-4)$, a $1,3,4,6$-tetrasubstituted benzene ring bearing an $o$-methylenedioxy moiety at $\delta_{\mathrm{H}} 6.11$ $\left(2 \mathrm{H}, s,-\mathrm{OCH}_{2} \mathrm{O}-\right)$, and characteristic singlets of the aromatic protons at $\delta_{\mathrm{H}} 6.93(1 \mathrm{H}, s, \mathrm{H}-5), 7.07(1 \mathrm{H}, s, \mathrm{H}-8)$ were observed.

\section{Conclusions}

The present study isolated phytosterols (1-3), coumarins (4 and 5) in the $n$-hexane- and dichloromethane-soluble fractions, and polar compounds: thymoquinol glucoside (6), $o$-hydroxycinnamic acid derivatives (7-9), and kaempferol diglucoside (10) in the water-soluble fraction from the leaves of E. triplinerve growing in Vietnam. Compounds 6-10 were isolated for the first time from E. triplinerve. We provided an efficient approach towards rapid identification of coumarins in E. triplinerve by NMR and HPLC analysis. Coumarins 4 and 5 were confirmed as the main constituents in the leaf extracts by proton NMR profiling and quantitative RPHPLC-PDA analysis. In the inhibitory activity, test against yeast $\alpha$-glucosidase of compounds 4-9, coumarins 4 and $\mathbf{5}$, and (E)-4-hydroxy-2-methoxycinnamic acid (7) showed $40 \%, 46 \%$, and $81 \%$ inhibitory activity, respectively, at $256 \mu \mathrm{g} / \mathrm{mL}$. The half inhibitory concentration $\left(\mathrm{IC}_{50}\right)$ of compound 7 was determined as $58.65 \pm 1.20 \mu \mathrm{g} / \mathrm{mL}$ $(302 \mu \mathrm{M})$ which is lower than that of the positive control acarbose $(197.33 \pm 2.51 \mu \mathrm{g} / \mathrm{mL}, 306 \mu \mathrm{M})$.

\section{Data Availability}

The data used to support the findings of this study are available from the corresponding author upon request.

\section{Conflicts of Interest}

The authors declare that they have no conflicts of interest.

\section{Authors' Contributions}

PMG designed the work and performed the research (isolation, structure determination, and NMR profiling) and wrote the manuscript. DTVH performed the HPLC analysis and enzyme inhibitory activity test. VMT contributed to the preparation of analytical samples.

\section{Acknowledgments}

This research was funded by Vietnam National Foundation for Science and Technology Development (NAFOSTED) under Grant no. 104.01-2017.41.

\section{Supplementary Materials}

MS and NMR data and spectra of compounds 1-10, NMR spectra of the methanol, and boiling water extracts are freely available along with the manuscript as supplementary materials. (Supplementary Materials)

\section{References}

[1] P. Y. Liu, D. Liu, W. H. Li et al., "Chemical constituents of plants from the genus Eupatorium (1904-2014)," Chemistry \& Biodiversity, vol. 12, no. 10, pp. 1481-1515, 2015.

[2] A. C. N. Sobrinho, S. M. de Morais, E. B. de Souza, and R. O. dos Santos Fontenelle, "The genus Eupatorium L. (Asteraceae): a review of their antimicrobial activity," Journal of Medicinal Plants Research, vol. 11, no. 3, pp. 43-57, 2017.

[3] http://www.ydhvn.com.

[4] J. G. S. Maia, M. G. B. Zoghbi, M. H. L. Da Silva, and E. H. A. Andrade, "Essential oils of Eupatorium triplinerve Vahl and E. paniculatum Poepp. et Endl," Journal of Essential Oil Research, vol. 11, no. 5, pp. 541-544, 1999.

[5] D. Gupta, R. Charles, and S. N. Garg, "Chemical composition of the essential oil from the leaves ofEupatorium 
triplinerveVahl," Journal of Essential Oil Research, vol. 16, no. 5, pp. 473-475, 2004.

[6] J. Begum and M. Bhuiyan, "Chemical composition and antimicrobial activity of essential oil from Eupatorium triplinerve Vahl. aerial parts," Asian Journal of Microbiology Biotechnology \& Environmental Science, vol. 12, no. 3, pp. 543-547, 2010.

[7] P. K. Bose and P. B. Sen, "New haemostatic agents. Part-I. Experiments with ayapanin and ayapin," Annals of Biochemistry and Experimental Medicine, vol. 4, pp. 311-316, 1941.

[8] J. A. da Souza and G. L. Pozetti, "Blood coagulation activity of the ayapin (6,7-metilen-dioxy-coumarin) obtained from Alomia fastigiata Benth (Compositae)," Revista da Faculdade de Farmacia e Odontologia de Araraquara, vol. 8, no. 2, pp. 123-127, 1974.

[9] K. N. Venugopala, V. Rashmi, and B. Odhav, "Review on natural coumarin lead compounds for their pharmacological activity," BioMed Research International, vol. 2013, Article ID 963248, , 2013.

[10] B. V. Cheriyan, P. Kadhirvelu, J. Nadipelly, J. Shanmugasundaram, V. Sayeli, and V. Subramanian, "Antinociceptive effect of 7-methoxy coumarin from Eupatorium triplinerve Vahl (Asteraceae)," Pharmacognosy Journal, vol. 13, no. 49, pp. 81-84, 2017.

[11] S. Kumala and D. W. Sapitri, "Phytochemical screening and toxicological evaluation using brine shrimp lethality test (BSLT) of some fractions of prasman leaves (Eupatorium triplinerve V) extract," Indonesian Journal of Cancer Chemoprevention, vol. 2, no. 1, pp. 193-197, 2011.

[12] A. O. Bose, M. Gupta, U. K. Mazumder, R. S. Kumar, H. Sivakumar, and R. S. Kumar, "Hepatoprotective and antioxidant effects of Eupatorium ayapana against carbon tetrachloride induced hepatotoxicity in rats," IJPT, vol. 6, pp. 27-33, 2007.

[13] R. Rezaee, E. Behravan, J. Behravan et al., "Antigenotoxic activities of the natural dietary coumarins umbelliferone, herniarin and 7-isopentenyloxy coumarin on human lymphocytes exposed to oxidative stress," Drug and Chemical Toxicology, vol. 37, no. 2, pp. 144-148, 2014.

[14] A. Mahdavi, P. Moradi, and A. Mastinu, "Variation in terpene profiles of Thymus vulgaris in water deficit stress response," Molecules, vol. 25, no. 5, p. 1091, 2020.

[15] H. Li, Y. Yao, and L. Li, "Coumarins as potential antidiabetic agents," Journal of Pharmacy and Pharmacology, vol. 69, no. 10, pp. 1253-1264, 2017.

[16] A. Kumar, M. Premoli, F. Aria et al., "Cannabimimetic plants: are they new cannabinoidergic modulators?" Planta, vol. 249, no. 6, pp. 1681-1694, 2019.

[17] E. H. M. Hassanein, A. M. Sayed, O. E. Hussein, and A. M. Mahmoud, "Coumarins as modulators of the Keap1/ Nrf2/ARE signaling pathway," Oxidative Medicine and Cellular Longevity, vol. 2020, p. 1, Article ID 1675957, 2020.

[18] A. Mastinu, S. Bonini, W. Rungratanawanich et al., "Gammaoryzanol prevents LPS-induced brain inflammation and cognitive impairment in adult mice," Nutrients, vol. 11, no. 4, p. 728, 2019.

[19] T. Nakagawa, A. Ashour, Y. Amen, Y. Koba, K. Ohnuki, and K. Shimizu, " $\alpha$-Glucosidase inhibitory activity of resin from Sakhalin fir tree (Abies sachalinensis) and its bioactive compounds," Natural Product Communications, vol. 2019, 2019.

[20] W. Benalla, S. Bellahcen, and M. Bnouham, "Antidiabetic medicinal plants as a source of alpha glucosidase inhibitors," Current Diabetes Reviews, vol. 2010, no. 4, pp. 247-254, 2010.
[21] S. Adisakwattana, "Cinnamic acid and its derivatives: mechanisms for prevention and management of diabetes and its complications," Nutrients, vol. 9, no. 2, p. 163, 2017.

[22] T. Li, X. D. Zhang, Y. W. Song, and J. W. Liu, "A microplatebased screening method for $\alpha$-glucosidase inhibitors," Chinese Journal of Clinical Pharmacology and Therapeutics, vol. 2005, no. 10, pp. 1128-1134, 2005.

[23] P. M. Giang, N. T. Thuy, D. H. Nam, T. T. H. Thu, and D. T. V. Huong, "Phenolic compounds, terpenoids, and sterols from Eupatorium japonicum Thunb. in Vietnam," Vietnam Journal of Chemistry, vol. 57, no. 2E, pp. 243-247, 2019.

[24] L. J. Goad and T. Akihisa, Analysis of Sterols, Blackie Academic \& Professional, London, UK, 1997.

[25] S. M. M. Mohamed, K. M. Elokely, E. Y. Bachkeet et al., "New glycosides and trypanocidal metabolites from Vangueria edulis," Natural Product Communications, vol. 10, no. 11, pp. 1897-1900, 2015.

[26] S. M. Valiahdi, M. Iranshahi, and A. Sahebkar, "Cytotoxic activities of phytochemicals from Ferula species," DARU Journal of Pharmaceutical Sciences, vol. 21, no. 1, 2013.

[27] F. Boeck, M. Blazejak, M. R. Anneser, and L. Hintermann, "Cyclization of ortho-hydroxycinnamates to coumarins under mild conditions: a nucleophilic organocatalysis approach," Beilstein Journal of Organic Chemistry, vol. 2012, no. 8, pp. 1630-1636, 2012.

[28] N. Trang, M. Wanner, L. V. Phuong, G. Koomen, and N. Dung, "Thymoquinone from Eupatorium ayapana," Planta Medica, vol. 59, no. 1, p. 99, 1993.

[29] M. S. Kamel, M. H. Assaf, H. A. Hasanean, K. Ohtani, R. Kasai, and K. Yamasaki, "Monoterpene glucosides from Origanum syriacum," Phytochemistry, vol. 58, no. 8, pp. 1149-1152, 2001.

[30] O. Hofer, G. Szabó, and H. Greger, "2-Hydroxy-4-methoxytrans-cinnamic acid as a precursor of herniarin in Artemisia dracunculus," Monatshefte für Chemie - Chemical Monthly, vol. 117, no. 10, pp. 1219-1222, 1986.

[31] H. Chen, H. Jiang, and J. A. Morgan, "Non-natural cinnamic acid derivatives as substrates of cinnamate 4-hydroxylase," Phytochemistry, vol. 68, no. 3, pp. 306-311, 2007.

[32] G. Zhang, F. Zhang, L. Yang et al., "Simultaneous analysis of trans- and cis-isomers of 2-glucosyloxycinnamic acids and coumarin derivatives in Dendrobium thyrsiflorum by highperformance liquid chromatography (HPLC)-photodiode array detection (DAD)-electrospray ionization (ESI)-tandem mass spectrometry (MS)," Analytica Chimica Acta, vol. 571, no. 1, pp. 17-24, 2006.

[33] F. H. Afshar, A. Delazar, H. Nazemiyeh et al., "Melilotoside derivatives from Artemisia splendens (Asteraceae)," Records of Natural Products, vol. 11, no. 1, pp. 43-50, 2017.

[34] T. Tsushida and M. Suzuki, "Flavonoid in fruits and vegetables Part I. Isolation of flavonoid-glycosides in onion and identification by chemical synthesis of the glycosides," Nippon Shokuhin Kagaku Kogaku Kaishi, vol. 42, no. 2, pp. 100-108, 1995.

[35] T. R. M. Lopes, F. R. de Oliveira, F. F. Malheiros, M. A. de Andrade, M. C. Monteiro, and A. C. B. Gonçalves, "Antimicrobial bioassay-guided fractionation of a methanol extract of Eupatorium triplinerve," Pharmaceutical Biology, vol. 53, no. 6, pp. 897-903, 2015.

[36] N. El Omari, K. Sayah, S. Fettach et al., "Evaluation of in vitro antioxidant and antidiabetic activities of Aristolochia longa extracts," Evidence-Based Complementary and Alternative Medicine, vol. 2019, Article ID 7384735, , 2019. 
[37] A. Ishikawa, H. Yamashita, M. Hiemori et al., "Characterization of inhibitors of postprandial hyperglycemia from the leaves of Nerium indicum," Journal of Nutritional Science and Vitaminology, vol. 53, no. 2, pp. 166-173, 2007.

[38] D. S. Rycroft, "Fingerprinting of plant extracts using NMR spectroscopy: application to small samples of liverworts," Chemical Communications, vol. 1996, no. 18, pp. 2187-2188, 1996.

[39] J.-L. Wolfender, G. Marti, and E. Ferreira Queiroz, "Advances in techniques for profiling crude extracts and for the rapid identificationof natural products: dereplication, quality control and metabolomics," Current Organic Chemistry, vol. 14, no. 16, pp. 1808-1832, 2010.

[40] S. Safer, S. S. Cicek, V. Pieri et al., "Metabolic fingerprinting of Leontopodium species (Asteraceae) by means of ${ }^{1} \mathrm{H}$ NMR and HPLC-ESI-MS," Phytochemistry, vol. 72, no. 11-12, pp. 1379-1389, 2011.

[41] J.-S. Yoo, E.-M. Ahn, M.-C. Song et al., "Quantitative analysis of coumarins from Angelica gigas using ${ }^{1} \mathrm{H}-\mathrm{NMR}$," Food Science Biotechnology, vol. 17, no. 3, pp. 573-577, 2008.

[42] E. J. Kim, J. Kwon, S. H. Park et al., "Metabolite profiling of Angelica gigas from different geographical origins using ${ }^{1} \mathrm{H}$ NMR and UPLC-MS analyses," Journal of Agricultural and Food Chemistry, vol. 59, no. 16, pp. 8806-8815, 2011. 